\title{
PENENTUAN LIMIT DETEKSI PENGUJIAN GAS HIDROGEN KLORIDA (HCI) DARI EMISI SUMBER TIDAK BERGERAK MENGGUNAKAN KROMATOGRAFI ION
}

\author{
DETERMINATION OF LIMIT DETECTION OF HYDROGEN CHLORIDE \\ (HCl) TESTING IN FLUE GAS USING ION CHROMATOGRAPHY
}

\author{
Retno Puji Lestari, Resi Gifrianto dan Anwar Hadi ${ }^{1)}$ \\ (Diterima tanggal 27 Februari 2017; Disetujui tanggal 8 Mei 2017)
}

\begin{abstract}
ABSTRAK
Pengujian kadar gas hidrogen klorida $(\mathrm{HCl})$ dari emisi sumber tidak bergerak yang dilakukan oleh laboratoriumlaboratorium lingkungan di Indonesia mengacu pada SNI 19-7117.8-2005. Di dalam metode spektrofotometri tersebut digunakan beberapa bahan berbahaya dan beracun (B3) antara lain merkuri tiosianat, metanol,dan asam perklorat. Laboratorium P3KLL menentukan limit deteksi terhadap metode uji yang diadopsi dari JIS K 0107-1995 menggunakan instrumen kromatografi ion DIONEX ICS5000. Instrumen IC5000 dilengkapi dengan detektor konduktivitas, penggunaan EGC (Eluent Generator Cartridge) yang ditambahkan dengan Carbonate Removal, dan mempunyai ukuran loop sampel 50 $\mu$ L. Kolom separator IonPac AS18 dengan kolom penjaga IonPAc AG18 dan

suppressor ASRS-II digunakan pada suhu 35 C. Larutan yang digunakan sebagai eluen adalah $\mathrm{H}_{2} \mathrm{O}(\mathrm{DHL}<$ $1 \mu \mathrm{S} / \mathrm{cm}$ ) pada laju alir $1 \mathrm{~L} /$ menit. Tahapan kegiatan terdiri dari persiapan, pengambilan contoh uji dan validasi metoda. Pengambilan contoh uji dilakukan tiga kali di insenerator sebagai bagian dari tahapan validasi yaitu mengkonfirmasi rentang uji. Dari hasil kajian tersebut, diperoleh $\mathrm{LoD}=0,6 \mathrm{mg} / \mathrm{Nm}^{3}, \mathrm{LoQ}=2 \mathrm{mg} / \mathrm{Nm}^{3}, \mathrm{dan}$ $\mathrm{LoL}=129 \mathrm{mg} / \mathrm{Nm}^{3}$, dimana JIS K 0107-1995 "Methods for Determination of Hydrogen Chloride in Flue Gas"memiliki rentang kerja $0,6-130 \mathrm{mg} / \mathrm{Nm}^{3}$. Disimpulkan bahwa metode terverifikasi sesuai tujuan dan laboratorium P3KLL mampu menunjukkan kompetensinya dalam menerapkan metode pengujian Hcl tersebut.
\end{abstract}

Kata kunci: hidrogen klorida, emisi sumber tidak bergerak, kromatografi ion

\begin{abstract}
Determination of hydrogen chloride $(\mathrm{HCl})$ in flue gas was conducted by the environmental laboratories in Indonesia according to the method of SNI 19-7117.8-2005. Within this spectrophotometry method, there are several toxic reagents were used such as mercury thiocyanate, methanol, and perchloric acid. Laboratory of P3KLL determined the limit detection from adopted method of JISK 0107-1995 using ion chromatography instrument, DIONEX ICS5000. The IC5000 equipped with conductivity detector, EGC (Eluen Generator Cartridge), Carbonate Removal, and 50 $\mu$ L sample loop. IonPac AS18 column, IonPAc Ag18 guard column and ASRS-II suppressor were used at $35 \mathrm{C}$. The eluent was $\mathrm{H}_{2} \mathrm{O}(\mathrm{EC}<1 \mu \mathrm{S} / \mathrm{cm})$ at a flow rate of $1 \mathrm{~L} / \mathrm{min}$. The sampling was conducted three times in incinerator as part of method validation i.e. confirmation of analytical range.The result showed that LoD of $0,6 \mathrm{mg} / \mathrm{Nm}^{3}, L o Q$ of $2 \mathrm{mg} / \mathrm{Nm}^{3}$ and LoL of $129 \mathrm{mg} / \mathrm{Nm}^{3}$ were obtained, whereas JIS K 0107-1995 "Methods for Determination of Hydrogen Chloride in Flue Gas"having a working range of $0,6-130 \mathrm{mg} / \mathrm{Nm}^{3}$. It is concluded that the method was verified according the goal, and the laboratory of P3KLL was able to show its competency in order to apply the testing method of $\mathrm{HCl}$.
\end{abstract}

Keywords: hydrogen chloride, flue gas emission, ionchromatography

${ }^{1}$ Pusat Penelitian dan Pengembangan Kualitas dan Laboratorium Lingkungan - Kementerian Lingkungan Hidup dan Kehutanan (P3KLL - KLHK) di Kawasan PUSPIPTEK Gedung 210 Serpong - Tangerang, Banten Telp/Faks. 021-7560981, email: emc_acdep@yahoo.com 


\section{PENDAHULUAN}

Pada prinsipnya, laboratorium dapat menggunakan metode standar mutakhir yang dipublikasikan secara internasional, regional, atau nasional. Selain itu, laboratorium dapat juga menggunakan metode non-standar yang diterbitkan oleh organisasi teknis yang mempunyai reputasi, jurnal ilmiah yang relevan, atau spesifikasi pabrik pembuat alat. Di sisi lain, ISO/IEC 17025 mensyaratkan bahwa laboratorium harus menggunakan metode pengujian yang memenuhi kebutuhan pelanggan. Sehubungan dengan hal tersebut, laboratorium harus melakukan pemilihan metode pengujian yang didasarkan pada sumber daya laboratorium yang tersedia, namun dapat memenuhi persyaratan serta kebutuhan pelanggan.

Terkait hal tersebut, penerapan SNI 19-7117.8-2005 tentang cara uji kadar hidrogen klorida $(\mathrm{HCl})$ dengan metoda m erkuritiosianatmenggunakan spektrofotometer pada emisi gas buang sumber tidak bergerak perlu dikaji ulang. Hal ini disebabkan karena beberapa bahan kimia yang digunakan dalam SNI 19-7117.8-2005 menggunakan bahan beracun dan berbahaya bagi manusia dan lingkungan hidup, yaitu $\mathrm{Hg}$ $(\mathrm{CNS})_{2}, \mathrm{CH}_{3} \mathrm{OH}$, maupun $\mathrm{HClO}_{4}$. Selain itu, metode ini kurang efisien karena membutuhkan waktu tunggu pembentukan warna selama 30 menit sebelum dilakukan pembacaan nilai serapan pada spektrofotometer. Sehubungan dengan hal tersebut, perlu dicari metode pengujian lain yang lebih efisien dan ramah lingkungan.
Salah satu metode pengujian $\mathrm{HCl}$ dalam emisi gas buang dari sumber tidak bergerak yang perlu dipertimbangkan adalah metode kromatografi ion (Ion Chromatography, IC). IC merupakan salah satu teknik pemisahan senyawa dalam larutan berdasarkan interaksi muatan positif dan negatif antara molekul spesifik dengan matriks yang berada di dalam kolom (11). Pengukuran anion dan kation dengan menggunakan metode IC dapat dilakukan pada konsentrasi relatif rendah terhadap senyawa-senyawa halogen seperti $\mathrm{HCl}(2,3), \mathrm{F}(4), \mathrm{Br}(5)$ dan gas-gas $\mathrm{NO}_{\mathrm{x}}(6)$ serta $\mathrm{SO}_{\mathrm{x}}(7,8)$. Metode IC dipilih karena preparasi yang sederhana, sensitivitas instrumen tinggi (9), serta menggunakan bahan kimia ramah lingkungan. Tahapan analisis yang dilakukan lebih efisien karena tidak membutuhkan penambahan bahan kimia dan pengujian dapat dilakukan secara simultan untuk ion-ion lainnya. Akan tetapi, metode ini membutuhkan investasi, biaya operasional, serta keterampilan analisis lebih tinggi untuk mengoperasikan instrumen IC. Ruang lingkup kajian ini adalah pengukuran $\mathrm{HCl}$ dengan larutan penjerap $\mathrm{H}_{2} \mathrm{O}$ menggunakan IC DIONEX ICS-5000. Instrumen IC tersebut dilengkapi dengan penggunaan EGC yang ditambahkan dengan Carbonate Removal, detektor konduktivitas, dan mempunyai ukuran loop sampel $50 \mu \mathrm{L}$. Kolom separator IonPac AS18 dengan kolom penjaga IonPAc AG18 dan suppressor ASRSII digunakan pada suhu $35^{\circ} \mathrm{C}$. Larutan yang digunakan sebagai eluen adalah $\mathrm{H}_{2} \mathrm{O}(\mathrm{DHL}<$ $1 \mu \mathrm{S} / \mathrm{cm}$ ) dengan laju alir $1 \mathrm{~L} / \mathrm{menit}$. Kajian ini terdiri dari pengambilan contoh uji 
yang dilakukan di suatu insenerator yang berlokasi di Jakarta, sementara proses analisis dilakukan di laboratorium udara Pusat Penelitian dan Pengembangan Kualitas dan Laboratorium Lingkungan - Kementerian Lingkungan Hidup dan Kehutanan (P3KLL

- KLHK) di Serpong. Metode pengujian mengacu pada JIS K 0107-1995 "Methods for Determination of Hydrogen Chloride in Flue Gas" yang memiliki rentang kerja 0,6 $-130 \mathrm{mg} / \mathrm{Nm}^{30}$.

\section{METODOLOGI}

Metode penentuan $\mathrm{HCl}$ dalam emisi gas buang sumber tidak bergerak menggunakan kromatografi ion berdasarkan pada teknik pemisahan anion klorida $\left(\mathrm{Cl}^{-}\right)$yang berasal dari hasil penjerapan gas $\mathrm{HCl}$ dari emisi sumber tidak bergerak dalam suatu kolom kromatografi menggunakan detektor konduktivitas.

Tahapan kegiatan kajian ini terdiri dari persiapan seluruh sumber daya laboratorium, pengambilan contoh uji di fasilitas incinerator dan validasi metode. Persiapan sumber daya mencakup evaluasi kelaikan peralatan pengambilan contoh uji, peralatan gelas, IC dan peralatan ukur yang mempengaruhi signifikan terhadap pengujian $\mathrm{HCl}$. Bahan kimia yang digunakan pada kajian ini adalah bahan kimia pro analisis komersial yaitu larutan standar $\mathrm{Cl}^{-} 1000 \mathrm{mg} / \mathrm{L}$ dari Cica-Reagent. Pengambilan contoh dilakukan sesuai metode SNI 19-7117.8-2005 (10) dengan modifikasi penggunaan larutan penjerap $\mathrm{H}_{2} \mathrm{O}$ sesuai JIS K 0107 - 1995 (2). Setelah pengambilan contoh uji dilakukan, larutan contoh uji dari kedua botol penjerap dipindahkan ke dalam labu ukur $100 \mathrm{~mL}$, dibilas dan diencerkan dengan air suling sampai tanda tera lalu dihomogenkan. Pembuatan larutan blanko diambil dari $100 \mathrm{~mL} \mathrm{H}_{2} \mathrm{O}$ (2).

Tahapan validasi metode dimulai dari pembuatan kurva kalibrasi pada rentang kerja metode sebagaimana tercantum pada JIS K 0107 - 1995. Pembuatan kurva kalibrasi ini bertujuan untuk menghitung batasan metode (Limit of Detection, LoD) dan batas kuantifikasi (Limit of Quantitation, LoQ). Sehubungan dengan penentuan LoD dan LoQ ini masih dalam satuan $\mathrm{mg} / \mathrm{L}$, maka nilai tersebut harus dikonversi ke dalam satuan udara $\left(\mathrm{mg} / \mathrm{Nm}^{3}\right)$ dengan mempertimbangkan data lapangan saat pengambilan sampel dilakukan. Penentuan batas linearitas (Limit of Linearity, LoL) dilakukan dengan pengukuran masing - masing 10 kali terhadap konsentrasi larutan standar terendah dan standar tertinggi (11). Standar deviasi masingmasing konsentrasi larutan tersebut dihitung dan dilakukan perhitungan uji F serta dibandingkan dengan nilai tabel-F.

Penentuan LoD dan LoQ ditentukan berdasarkan rumus sebagai berikut:

$$
L o D_{(L)}=x_{0}=\frac{y_{0}-a}{b} \text { dimana } y_{0}=a+3 s d_{x y}
$$

dengan demikian $\quad L o D_{(L)}=\frac{3 s d_{x y}}{b}$

Keterangan

$$
\begin{aligned}
& \mathrm{L}_{\circ} \mathrm{D}_{(\mathrm{L})}=\quad \text { Limit of Detection dalam } \\
& \text { larutan }(\mathrm{mg} / \mathrm{L}) \\
& \mathrm{X}_{\mathrm{o}}=\text { kadar dalam kurva } \\
& \text { kalibrasi yang digunakan } \\
& \text { untuk penentuan LoD }
\end{aligned}
$$




$$
\begin{aligned}
y_{0} & =\text { area dalam } \\
& \text { kurva yang digunakan } \\
& \text { untuk penentuan LoD } \\
a & =\text { intersep } \\
b & =\text { method slope }
\end{aligned}
$$

sedangkan LoQ ditentukan menggunakan persamaan sebagai

berikut :

$$
\mathrm{LoQ}_{(\mathrm{L})}=\quad \cdots \quad \sim \operatorname{dimana} \quad s d_{x y}
$$

Keterangan

$$
\begin{aligned}
\mathrm{Lo}_{\mathrm{o}} \mathrm{L}_{\mathrm{L})=} & \text { Limit of Quantitation dalam } \\
& \text { larutan }(\mathrm{mg} / \mathrm{L}) \\
\mathrm{x}_{1}= & \text { kadar dalam kurva kalibrasi } \\
& \text { yang digunakan untuk } \\
& \text { penentuan LoQ } \\
\mathrm{y}_{1}= & \text { area dalam kurva kalibrasi } \\
& \text { yang digunakan untuk } \\
& \text { penentuan LoQ } \\
\mathrm{a}= & \text { intersep } \\
\mathrm{b}= & \text { method slope }
\end{aligned}
$$

Sehubungan dengan $\operatorname{LoD}_{(\mathrm{L})}$ dan $\operatorname{LoQ}_{(\mathrm{L})}$ yang diperoleh masih dalam satuan $\mathrm{mg} / \mathrm{L}$ dikarenakan penentuan hanya menggunakan kurva kalibrasi regresi linear, maka dilakukan konversi dengan mempertimbangkan jumlah volume larutan $\mathrm{Hcl}$ yang digunakan saat pembacaan IC dan data pengukuran lapangan volume udara yang dihisap dikoreksi pada kondisi normal dan dihitung dengan persamaan sebagai berikut:

$$
V_{s}=V \times \frac{298}{298+t} \times \frac{\left(P_{a}+P_{m}\right)}{760}
$$

keterangan:

$\mathrm{V}_{\mathrm{s}}=$ volume contoh uji gas pada kondisi normal $25^{\circ} \mathrm{C}, 760 \mathrm{mmHg}\left(\mathrm{Nm}^{3}\right)$

$\mathrm{V}=$ volume contoh uji gas yang dihisap (L)
$\mathrm{P}_{\mathrm{a}}=$ tekanan atmosfer $(\mathrm{mmHg})$

$\mathrm{P}_{\mathrm{m}}=$ tekanan gauge yang dibaca pada gas meter $\left(\mathrm{mmH}_{2} \mathrm{O}\right)$ dan dikonversi ke satuan $\mathrm{mmHg}$

Dengan demikian, $\operatorname{LoD}_{(\mathrm{G})}$ dan $\operatorname{LoQ}_{(\mathrm{G})}$ diperoleh sebagai berikut:

$$
\operatorname{LoD}_{(G)}=\frac{\operatorname{LoD}_{(L)}}{V_{s}} V_{(H C l)} \frac{B M_{H C l}}{B A_{C l}}
$$

$$
L o Q_{(G)}=\frac{L o Q_{(L)}}{V_{s}} V_{(H C l)} \frac{B M_{H C l}}{B A_{C l}}
$$

$$
\begin{aligned}
& \text { koD } \quad \text { limit of detection dalam } \\
& \text { (G) } \quad \text { larutan }\left(\mathrm{mg} / \mathrm{Nm}^{3}\right) \text { limit } \\
& \text { LoD of detection dalam } \\
& \text { larutan }(\mathrm{mg} / \mathrm{L}) \\
& \text { limit of quantitation } \\
& { }^{\mathrm{LoQ}_{(\mathrm{G})}=} \quad \text { dalam larutan }\left(\mathrm{mg} / \mathrm{Nm}^{3}\right) \\
& \text { limit of quantitation } \\
& { }^{\mathrm{LoQ}}(\mathrm{L})=\quad \text { dalam larutan }(\mathrm{mg} / \mathrm{L}) \\
& \mathrm{V}_{(\mathrm{HCl})}=\text { volume } \\
& \text { akhir larutan contoh uji } \\
& \mathrm{HCl}=100 \mathrm{~mL}=0,1 \mathrm{~L} \\
& \mathrm{~V}_{\mathrm{s}} \quad=\text { volume contoh uji } \\
& \text { gas pada kondisi normal } 25^{\circ} \mathrm{C} \text {, } \\
& 760 \mathrm{mmHg}\left(\mathrm{Nm}^{3}\right) \\
& \mathrm{BM}_{\mathrm{HCl}}=\text { berat molekul } \mathrm{HCl}=36,5 \\
& \mathrm{BA}_{\mathrm{Cl}}=\text { berat atom } \mathrm{Cl}=35,5
\end{aligned}
$$

\section{HASIL DAN PEMBAHASAN}

Hasil pengujian senyawa halogen dan $\mathrm{SO}_{\mathrm{X}}$ secara simultan dari emisi sumber tidak bergerak dengan larutan penjerap $\mathrm{NaOH} 0,1$ $\mathrm{N}$ telah dilakukan oleh Nonomura dan Kurita (2011) menggunakan instrumen IC DIONEX DX500 dengan loop sampel berukuran $25 \mathrm{~mL}$ (12). Dalam metode tersebut digunakan 
kolom separator IonPac AS12A dengan kolom penjaga IonPAc AG12 dan suppressor ASRS-II pada suhu $35^{\circ} \mathrm{C}$. Larutan yang d i g u n a k a n s e b a g a i e $1 \mathrm{u}$ e $\mathrm{n}$ a d a $1 \mathrm{a} \mathrm{h}$ $\mathrm{Na}_{2} \mathrm{CO}_{3} 2,7 \mathrm{mM}+\mathrm{NaHCO}_{3}$ 0,3 mM dengan laju alir $1.3 \mathrm{~L} /$ menit (12). Penelitian tersebut lebih menekankan pada pengukuran parameter halogen yaitu $\mathrm{F}^{-}$dan $\mathrm{Cl}^{-}$serta $\mathrm{SOx}$.

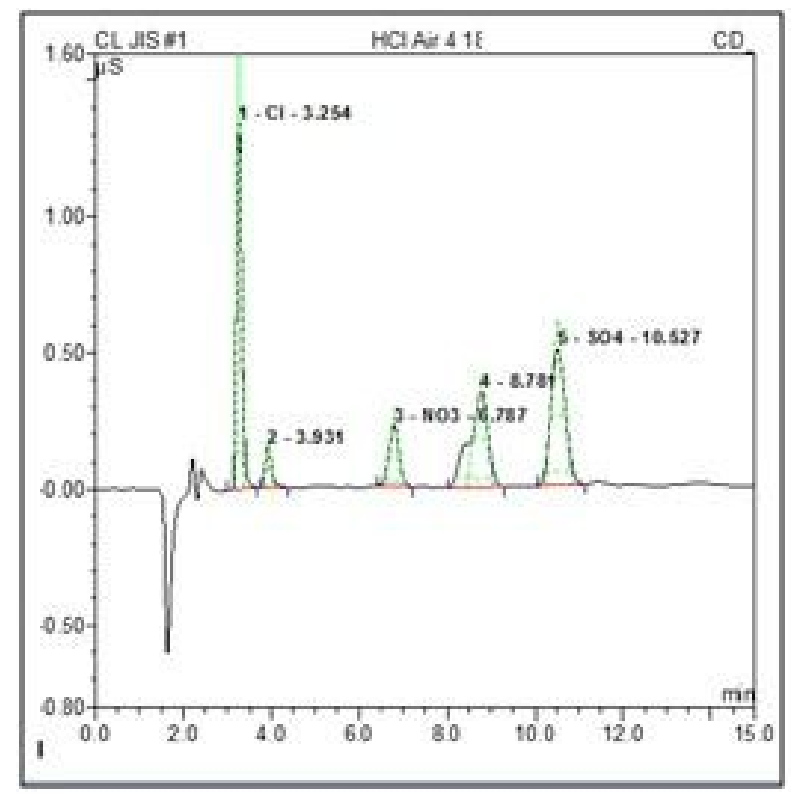

Hasil analisis IC DIONEX ICS5000 yang dilengkapi dengan EGC dan Carbonate Removal menggunakan eluen $\mathrm{H}_{2} \mathrm{O}$ akan menunjukkan kromatogram yang sedikit berbeda dengan IC DIONEX DX500 maupun ICS5000 yang memakai eluen $\mathrm{Na}_{2} \mathrm{CO}_{3} 2,7 \mathrm{mM}$ dan $\mathrm{NaHCO}_{3} 0,3 \mathrm{mM}$.

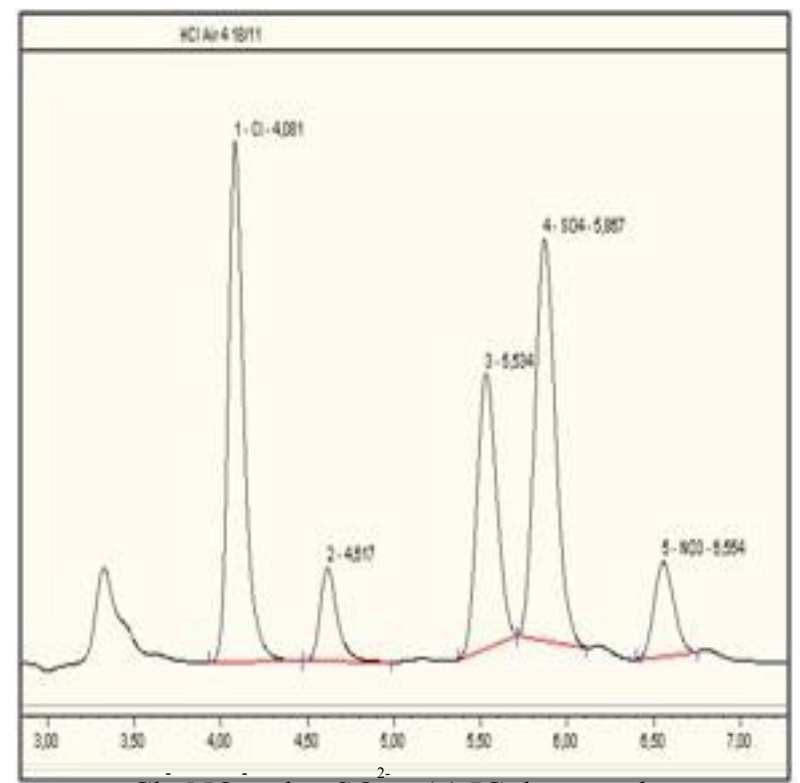

Gambar 1: Kromatogram IC DIONEX ICS5000 untuk parameter $\mathrm{Cl}$, $\mathrm{NO}_{3}$, dan $\mathrm{SO}_{4}$, (a) IC dengan eluen campuran $\mathrm{Na}_{2} \mathrm{CO}_{3} 2,7 \mathrm{mM}$ dan $\mathrm{NaHCO}_{3} 3 \mathrm{mM}$, (b) IC menggunakan ECG dan Carbonate Removal dengan eluen $\mathrm{H}_{2} \mathrm{O}$.

Pada gambar 1(a) terlihat adanya water dip sebelum kromatogram-kromatogram anion muncul, dimana hal ini lazim terjadi akibat penggunaan eluen karbonat. Namun demikian, apabila melakukan analisis senyawa halogen secara simultan adanya water dip akan berpengaruh pada pembacaan peak anion $\mathrm{F}^{-}$ dengan konsentrasi rendah, karena $\mathrm{F}^{-}$memiliki waktu retensi (Rt) lebih kecil $\mathrm{Cl}^{-}$.

Hal ini dapat diatasi dengan penggunaan EGC dan carbonate removal. Fungsi EGC adalah membuat eluen secara otomatis untuk mengurangi kesalahan operator. Carbonate

removal berfungsi sebagai penghilang karbonat dalam contoh uji karena $\mathrm{CO}_{3}$ dapat mengganggu pembacaan peak bagi $\mathrm{F}^{-}$dan $\mathrm{Cl}^{-}$. Adanya kedua fitur di atas akan memberikan hasil pembacaan peak lebih baik, tidak diperlukan penukaran ion dengan penyaringan menggunakan resin dan tidak diperlukan proses aerasi guna menghilangkan pengganggu karbonat, karena aerasi akan mengurangi

konsentrasi $\mathrm{NO}_{3}$ di dalamnya (1).

Penentuan LoD dan LoQ pengujian gas $\mathrm{HCl}$ dari emisi sumber tidak bergerak menggunakan metode kromatografi ion dilakukan melalui 
penentuan kurva kalibrasi dengan mengukur area kromatogram pada deret kurva standar skala penuh tanpa blanko. Hasil pengukuran dihitung untuk mencari persamaan garis dan linearitas seperti terlihat pada tabel berikut:

Tabel 1: Pembuatan kurva kalibrasi

\begin{tabular}{|c|c|c|c|}
\hline $\begin{array}{l}\text { Larutan } \\
\text { Standar }\end{array}$ & $\begin{array}{c}\text { Konsentrasi } \\
(\mathrm{mg} / \mathrm{L})\end{array}$ & Area & \\
\hline Std-1 & 0,020 & 0,0103 & \\
\hline Std-2 & 0,100 & 0,0321 & \\
\hline Std-3 & 0,400 & 0,1369 & \\
\hline Std-4 & 0,800 & 0,2481 & \\
\hline Std-5 & 1,400 & 0,4523 & \\
\hline Std-6 & 2,000 & 0,6374 & \\
\hline Std-7 & 3,000 & 0,9615 & \\
\hline Std-8 & 5,000 & 1,5812 & \\
\hline Std-9 & 10,000 & 3,1952 & \\
\hline Std-10 & 15,000 & 4,7447 & \\
\hline Std-11 & 20,000 & 6,3494 & \\
\hline Std-12 & 25,000 & 7,9635 & Gambar 2: Kurva Kalibrasi penentuan LoD LoQ \\
\hline
\end{tabular}

Berdasarkan kurva kalibrasi, diperoleh persamaan regresi linear $\mathrm{y}=0,378 \mathrm{x}+0,002$ dengan koefisien determinasi $\stackrel{2}{R})=1$ dan standar deviasi residual $\left(\operatorname{sd}_{\mathrm{xy}}\right)=0,0121$. Sebelum persamaan regresi linear tersebut digunakan lebih lanjut untuk menentuan LoD dan LoQ, maka perlu dilakukan evaluasi dengan membandingkan batas keberterimaan sebagai berikut:

\begin{tabular}{lccc} 
Keterangan & Nilai & Batas keberterimaan & Kesimpulan \\
\hline $\begin{array}{l}\text { Method slope }(\mathrm{b}) \\
\text { Intersep (a) }\end{array}$ & 0,3178 & -------- & \\
& 0,0020 & $(\mathbf{a} / \mathbf{b}) \leq 0,4 \times$ kadar terendah & \\
& & $\mathbf{( 0 , 0 0 2 0 / 0 , 3 1 7 8}) \leq 0,4 \times 0,02$ & \\
Koefisien determinasi $\left(\mathrm{R}^{2}\right)$ & 1,0000 & $\mathbf{0 , 0 0 6} \leq 0,008$ & Diterima \\
Koefisien korelasi $(\mathrm{r})$ & 1,0000 & $\mathrm{R}^{2} \geq 0,990$ & Diterima \\
Standar deviasi residual $\left(\mathrm{sd}_{\mathrm{xy}}\right)$ & 0,0121 & $\mathrm{r} \geq 0,995$ & Diterima \\
\hline \multicolumn{2}{l}{ Kesimpulan linearitas kurva kalibrasi adalah diterima } \\
\hline
\end{tabular}

Berdasarkan data tersebut di atas, maka dengan menggunakan persamaan LoD diperoleh:

$$
L o D_{(L)}=\frac{3 s d_{x y}}{b}=\frac{3(0,0121)}{0,3178}=0,114 \mathrm{mg} / \mathrm{L}
$$


Sedangkan dengan menggunakan persamaan LoQ, diperoleh :

$$
L o Q_{(L)}=\frac{3 s d_{x y}}{b}=\frac{10(0,0121)}{0,3178}=0,381 \mathrm{mg} / \mathrm{L}
$$

Jika data pengukuran lapangan, diperoleh data sebagai berikut :

- Volume larutan $=0,2 \mathrm{~mL}$
$=20$ liter

- Volume udara yang $=20$ liter dihisap (V)

- Suhu udara (t) $=30^{\circ} \mathrm{C}$

- Tekanan atmosfer $\left(\mathrm{P}_{\mathrm{a}}\right)=760 \mathrm{mmHg}$

- Tekanan gauge dibaca $=0,294 \mathrm{mmHg}$ pada gas meter $\left(\mathrm{P}_{\mathrm{m}}\right)$

maka :

$$
\left.L o D_{(G)}=\frac{L O D_{(L)}}{V_{S}}{ }_{H}{ }_{H C l} \quad\right)=\frac{0,114}{0,0197} \underset{(0,1)}{35,5}=0, \frac{36,5}{35,5}=0 \mathrm{mg} / \mathrm{Nm}^{3}
$$

dan :

$$
\underset{L o Q}{(G)}=\frac{\operatorname{LoQ}(L)}{V}\left(V_{H C l}\right)=\frac{0,381}{0,0197}(0,1) \underline{36,5}=2 \mathrm{mg} / \mathrm{Nm}^{3}
$$

Dalam implementasinya, ketika hasil pengujian $\mathrm{HCl}$ dalam emisi gas buang sumber tidak bergerak kurang dari $0,6 \mathrm{mg} / \mathrm{Nm}^{3}$, maka laboratorium P3KLL harus melaporkan kurang dari $\operatorname{LoD}_{(\mathrm{G})}$. Namun, jika hasil pengujian diantara $\operatorname{LoD}_{(\mathrm{G})}$ dan $\mathrm{LoQ}_{(\mathrm{G})}$, maka hasil

Tabel 3: Penentuan limit of linearity (LoL) pengujian dilaporkan tanpa menyertakan estimasi ketidakpastian. Ketika hasil pengujian lebih dari nilai $\operatorname{LoQ}_{(\mathrm{G})}$ hasil verifikasi, maka harus dilaporkan hasil dengan estimasi ketidak pastiannya (14).

Limit of linearity merupakan batas kadar tertinggi analit dari suatu metode pengujian tertentu. Rentang kadar antara LoQ dan LoL dalam kurva kalibrasi disebut rentang kerja (working range) metode pengujian. Rentang kerja metode tersebut harus merupakan garis lurus (linear) yang memenuhi batas keberterimaan statistika. Penetapan LoL dilakukan sesuai tahapan pengerjaan yaitu membuat minimum 7 deret kadar larutan kerja tanpa blanko dengan mempertimbangkan rentang pengujian metode yang sedang diverifikasi, kemudian melakukan 10 kali pengulangan pengukuran untuk kadar rendah dan kadar tinggi pada larutan kerja tersebut dan menghitung batas

\begin{tabular}{|c|c|c|c|c|c|c|c|c|c|c|c|c|}
\hline Standar & $\begin{array}{l}\text { Kadar } \\
(\mathrm{mg} / \mathrm{L})\end{array}$ & Area-1 & Area-2 & Area-3 & Area-4 & Area-5 & Area-6 & Area-7 & Area-8 & Area-9 & Area-10 & SD \\
\hline Std - 1 & 0.02 & 0.042 & 0.010 & 0.026 & 0.022 & 0.014 & 0.040 & 0.038 & 0.041 & 0.015 & 0.017 & 0.013 \\
\hline Std - 2 & 0.10 & & & & & & & & & & & \\
\hline Std - 3 & 0.40 & & & & & & & & & & & \\
\hline Std - 4 & 0.80 & & & & & & & & & & & \\
\hline Std - 5 & 1.40 & & & & & & & & & & & \\
\hline Std - 6 & 2.00 & & & & & & & & & & & \\
\hline Std - 7 & 3.00 & & & & & & & & & & & \\
\hline Std - 8 & 5.00 & & & & & & & & & & & \\
\hline Std - 9 & 10.00 & & & & & & & & & & & \\
\hline Std - 10 & 15.00 & & & & & & & & & & & \\
\hline Std - 11 & 20.00 & & & & & & & & & & & \\
\hline Std 012 & 25.00 & 7.937 & 7.930 & 7.919 & 7.904 & 7.922 & 7.978 & 7.983 & 7.937 & 7.910 & 7.933 & 0.026 \\
\hline
\end{tabular}
keberterimaan secara statistika (13). Dengan mempertimbangkan hal tersebut, maka diperoleh data sebagai berikut 
Pembuktian linearitas kurva kalibrasi sebagaimana Tabel 3 dapat dilakukan $\frac{\text { SUMMARY OUTPUT }}{\text { Regression Statistics }}$ dengan analysis of varian (anova). Anova dapat dihitung dengan menggunakan program excel sebagaimana ditampilkan, di bawah ini: 


\begin{tabular}{|c|c|c|c|c|c|}
\hline Multiple $R$ & & ,999991171 & & & \\
\hline$R$ Square & & ,999982342 & & & \\
\hline Adjusted R Squar & & ,999980577 & & & \\
\hline Standard Error & &, 012096946 & & & \\
\hline Observations & & 12 & & & \\
\hline & $d f$ & $S S$ & $M S$ & $F$ & Significance F \\
\hline Regression & 1 & 82,87311528 & 82,87311528 & 566320,3953 & $4,2243 \mathrm{E}-25$ \\
\hline Residual & 10 & 0,001463361 & 0,000146336 & & \\
\hline Total & 11 & 82,87457864 & & & \\
\hline
\end{tabular}

\begin{tabular}{|c|c|c|c|c|}
\hline & Coefficients & Standard Error & $t$ Stat & P-value \\
\hline Intercept & 0,002018404 & 0,004546312 & 0,443965039 & 0,666520446 \\
\hline$X$ Variable 1 & 0,317799555 & 0,000422301 & 752,5426203 & $4,2243 \mathrm{E}-25$ \\
\hline $\begin{array}{l}\text { hasil perhitu } \\
\text { koefisien } \\
\text { kapkan seba }\end{array}$ & $\begin{array}{l}\text { gan Anova me } \\
\text { regresi line } \\
\text { gai Multiple } R\end{array}$ & $\begin{array}{r}\text { erikan } \\
\text { yang } \\
0,995\end{array}$ & 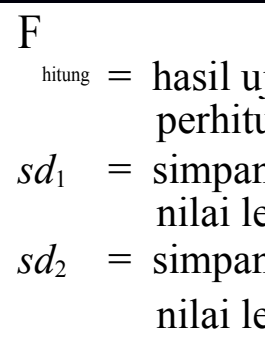 & $\begin{array}{l}\text { F berdasarkan } \\
\text { ngan } \\
\text { gan baku yang memiliki } \\
\text { bih besar } \\
\text { gan baku yang memiliki } \\
\text { pih kecil }\end{array}$ \\
\hline
\end{tabular}

\section{Significance $F \leq 0,05$ maka garis yang} terbentuk merupakan garis regresi linear. Sehubungan dengan kadar deret larutan kerja $\mathrm{HCl}$ dengan area sebagai respon i $\mathrm{n} \mathrm{s}$ r u m e n I C m e n g h a s i $1 \mathrm{kannila} \mathrm{i}$ Multiple $R=0,99999 \mathrm{~d}$ annila i Significance $F=4,2243 \cdot 10^{-25}$, maka dapat disimpulkan bahwa garis yang terbentuk merupakan garis regresi linear.

Berdasarkan data dalam Tabel 3 tersebut diatas, uji-F digunakan untuk membanding kan dua simpangan baku sesuai persamaan. Dengan membandingkan kedua simpangan baku data hasil pengulangan pengujian, maka presisi dapat diketahui hampir sama atau beda nyata.
Hasil perhitungan $F_{\text {hitung }}$ dibandingkan dengan nilai kritis dari tabel $F\left(F_{\text {tabel }}\right)$. Untuk mendapat nilai kritis dari tabel $\mathrm{F}$ maka derajat kebebasan untuk kedua simpangan baku $s d_{1}$ dan $s d_{2}$ didasarkan kepada:

$$
d f_{1}=n_{1}-1 \quad \text { dan } \quad d f_{2}=n_{2}-1
$$

dimana

$$
\begin{aligned}
d f= & \text { derajat kebebasan pengujian } \\
& \text { pertama } \\
d f_{2}= & \text { derajat kebebasan pengujian } \\
& \text { kedua } \\
n_{1}= & \text { jumlah pengulangan pengujian } \\
& \text { pertama } \\
n_{2}= & \text { jumlah pengulangan pengujian } \\
& \text { kedua }
\end{aligned}
$$


Jika $\mathrm{F}_{\text {nitung }} \leq \mathrm{F}_{\text {tabel }} \underset{\text { tingkat }}{\text { dengan }}$

kepercayaan $99 \%(\alpha=0,01)$, maka dapat disimpulkan bahwa kedua data hasil pengujian memiliki presisi yang tidak

beda nyata. Nilai $F_{\text {tabel }}$ diperoleh dari tabel F untuk $\mathrm{F}_{(a ; \mathrm{df} 1 ; \mathrm{d} 2)}$ atau $\mathrm{F}_{(0,01 ; \mathrm{n} 1-1 ; \mathrm{n} 2-1)}$.

$$
F \quad=\frac{s d^{2}}{s d^{2}}=\frac{(0,026)^{2}}{(0,013)^{2}}=4,359
$$

Sehubungan dengan derajat kebebasan $d f_{1}=d f_{2}=\mathrm{n}-1 \&$ tingkat kepercayaan 99\% maka diperoleh $\mathrm{F}_{\text {tabel }}=\mathrm{F}_{(0,01 ; 9 ; 9)}=5,351$ (Tabel 4). Dari data perhitungan tersebut, maka diketahui bahwa $\mathrm{F}_{\mathrm{h} \text { it u } \mathrm{g}}<\mathrm{F}_{\mathrm{ta} \text { a e } 1}$. Dengan demikian, dapat disimpulkan bahwa dengan tingkat kepercayaan 99\% maka 0,02 - 25mg $\mathrm{HCl} / \mathrm{L}$ merupakan regresi linear dan $25 \mathrm{mg} \mathrm{HCl} / \mathrm{L}$ merupakan LoL.

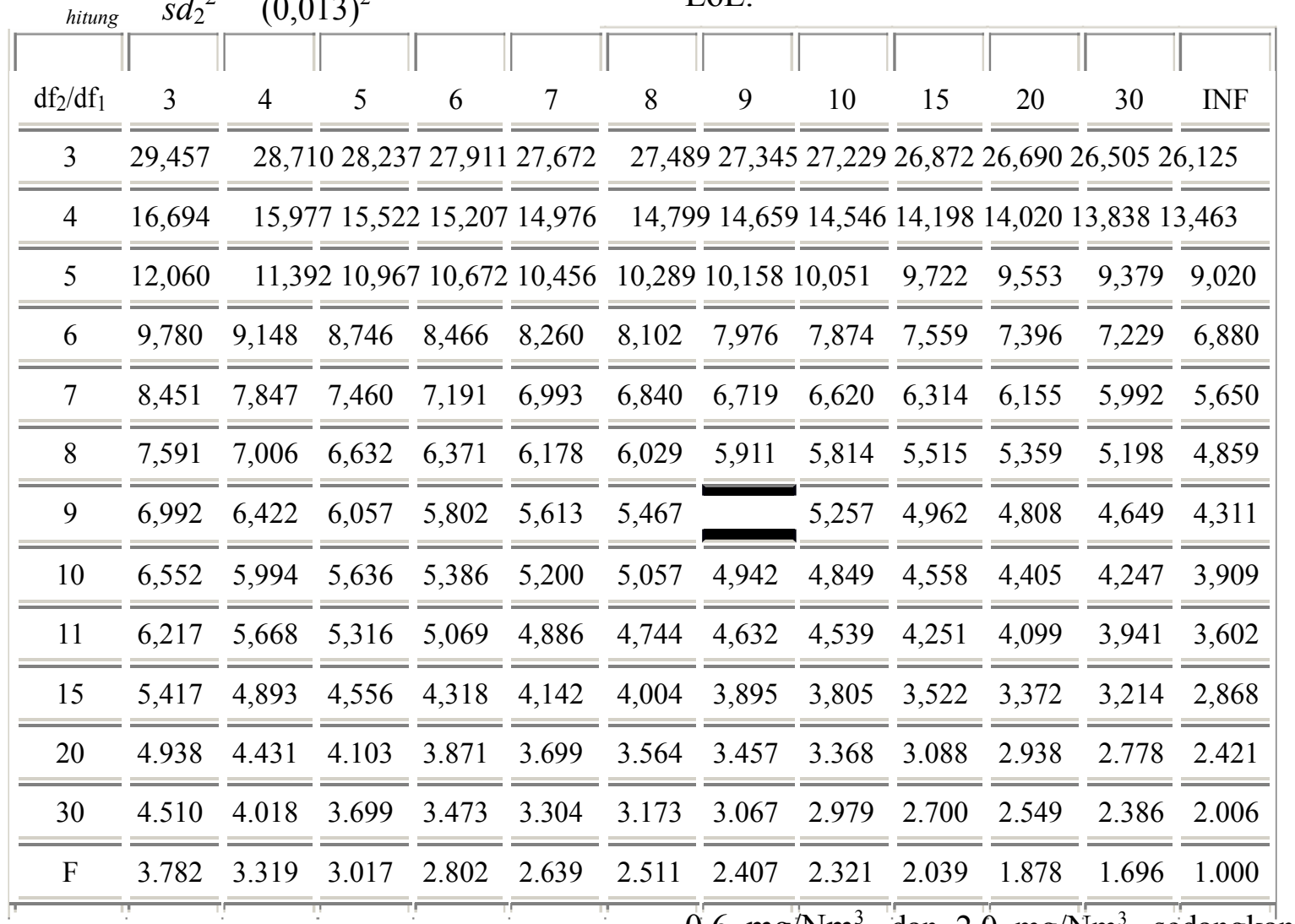

Hasil penentuan LoL pada Tabel 3. m e $n$ u $n$ j u k k a n b a h w a 25 m g / L (129mg/ $\mathrm{Nm}^{3}$ ) adalah batas linearitas pengujian $\mathrm{HCl}$ dengan kromatografi ion.

\section{SIMPULAN}

Berdasarkan verifikasi metode pengujian $\mathrm{HCl}$ dalam emisi gas buang sumber tidak bergerak menggunakan kromatografi ion, didapatkan hasil $\operatorname{LoD}_{(\mathrm{G})}$ dan $\operatorname{LoQ}_{(\mathrm{G})}$ adalah
$0,6 \mathrm{mg} / \mathrm{Nm}^{3}$ dan $2,0 \mathrm{mg} / \mathrm{Nm}^{3}$, sedangkan LoL $=129 \mathrm{mg} / \mathrm{Nm}^{3}$. Jika hasil verifikasi metode pengujian tersebut dibandingkan $\mathrm{d}$ e $\mathrm{n} g$ a n m e t o d e a c u a n n y a y a i t u JIS K 0107-1995 "Methods for Determination of Hydrogen Chloride in Flue Gas" yang memiliki rentang kerja $0,6-130 \mathrm{mg} / \mathrm{Nm}^{3}$, maka dapat disimpulkan bahwa metode terverifikasi sesuai tujuan dan laboratorium P3KLL mampu menunjukkan kompetensinya 
dalam menerapkan metode pengujian $\mathrm{HCl}$ tersebut.

\section{UCAPAN TERIMA KASIH}

Penulis mengucapkan terima kasih pada tim sampling laboratorium udara dan pihak pemilik insenerator di Jakarta yang telah memberi ijin untuk melakukan pengukuran.

\section{DAFTAR PUSTAKA}

1. DIONEX. Ion chromatography from basis to application. Dionex Ion Chromatography Seminar. Jakarta. 2010.

2. JIS. K 0107.

Methods for determination of hydrogen chloride in flue gas. Tokyo. 1995.

3. EPA. Method 26. Determination of hydrogen chloride emissions from stationary sources. US Environmental Protection Agency. p. 865.

4. JIS. K 0105.

Methods for determination of fluorine compounds in flue gas. Tokyo. 1998.

5. JIS. K 0085.

Methods for determination of bromine in flue gas. Tokyo. 2000.

6. EPA. Method 7A. Determination of nitrogen oxide emissions from stationary sources ion chromatographic method. US. Environmental Protection Agency. p. 626.

7. ISO/DIS. 11632.

Stationary source emissions determination of sulphur dioxide-
International Organization for Standards; 1996.

8. JIS. K0103.

Methods for determination of sulphur oxides in flue gas. Tokyo: Japanese Standards Association; 2000.

9. Fosco T, Schmeling M.

Determination of water-soluble atmospheric aerosols using ion chromatography Environmental monitoring and assessment. 2007;130(1):187-99.

10. SNI. 19-7117.8-2005

Cara uji kadar gas hidrogen klorida di udara emisi sumber tidak bergerak dengan metode merkuri tiosianat Jakarta 2005.

11. Hadi A. Verifikasi metode pengujian parameter kualitas lingkungan. Jakarta. 2009.

12. Nonomura M, Kurita K. Simultaneous determination of halogen compounds and sulfur oxides in flue gas by Ion Chromatography. Journal of Chemistry and Chemical Engineering. 2011;5(4).

13. ISO 8466-1:2008:

Water quality - Calibration and evaluation of analytical methods and estimation of performance characteristics - Part 1: Statistical evaluation of the linear calibration function

14. APHA. Standard methods for the examination of water and wastewater, 22th edition. 2012. "1020 B:

Quality Control". American Public Health Association. Washington DC USA 
